\title{
Development of RGD peptides grafted onto chitosan surfaces; Osteoblast interactions
}

\author{
Chang-Kyun Lee ${ }^{1}$, Jeong-Hyo Hwang ${ }^{2}$, Yong-Moo Lee ${ }^{1}$, Young Ku' ${ }^{1}$ In-Chul Rhyu', \\ Seung-Jin Lee ${ }^{2}$, Soo-Boo Han ${ }^{1}$, Sang-Mook Choi ${ }^{1}$, Chong-Pyoung Chung ${ }^{1}$
}

\author{
${ }^{1}$ Department of Periodontology, College of Dentistry, Seoul National University \\ ${ }^{2}$ College of Pharmacy, Ewha Womans University
}

\section{INTRODUCTION}

The purpose of tissue engineering is to control the growth, differentiation, and behavior of the cells so that the cells can be organized into functional tissue and organ ${ }^{1-3)}$. One attempt of achieving this goal is forming of a defined micro-environment, thereby promoting specific interaction of surrounded cells. These micro-environments in tissue engineering are often required to mimic the micro-environment created by the body in natural cell and tissue development $^{3)}$

To create biomimetic micro-environments for tissue engineering applications, the modification of biomaterial surfaces has been performed. The surface of biomaterials is the first place of cell adhesion. The biocompatibility of biomaterials is very closely related to cell behavior on contact with them and particularly to cell adhesion to surface.

Many studies related to the biochemical surface modification of the biomaterials have been widely conducted to enhance their biocompatibility. For surface modification, the molecules such as amino acids, peptides, proteins, enzymes, and growth fac- tors are used ${ }^{4)}$. These molecules are bound onto the surface of biomaterials including metal, bone substitutes, and polymers. The concept of designing polymeric materials with precisely controlled and complex surface chemistries has been received much attention recently in biomaterial science ${ }^{5,6)}$.

Biomimetic micro-environment using polymeric materials can be created by covalent immobilization of bioactive molecules to the surface of polymeric materials. For anchorage-dependent cells, extracellular matrix (ECM) proteins seem to be proper surface modification. ECM proteins are important for controlling cell functions including adhesion, proliferation, and differentiation ${ }^{8)}$.

However, the in vivo usage of whole natural protein has been beset by the limitations including low material availability, immunogenecity, relatively high cost, and instability towards enzymatic degradation. Therefore, instead of whole natural protein, synthetic small peptides, which contain the active binding sequences of the natural protein, are regarded as attractive alternatives.

Some proteins, such as fibronectin, vitronectin, type I collagen and fibrinogen have been demon- 
strated to have chemotactic and/or adhesive properties, notably due to Arg-Gly-Asp (RGD) sequence, a specific ligand toward the cell attachment receptors such as integrin on the cell membrane.(8)

Herein, our investigation focused on the preparation of polymeric materials with RGD containing oligopeptides (GRGDS). We selected chitosan as a substrate because the biomedical applications of chitosan have been widely conducted over the past 20 years. The primary amine groups within chitosan play a crucial role in conjugating oligopeptide via amide bond formation. The peptide immobilization strategy involves the changing the terminal carboxylate to a carbodiimide-functional group by coupling a cross-linker[EDC, NHS] (Sigma, MO, USA) and the forming an amide bond by using a primary amine of chitosan and an activated carboxylate group of the peptide.

The aim of this study was to develop the chitosan surface modified with RGD containing oligopeptide and to investigate the biological effect of the modified chitosan surface using MG-63, human osteoblast like cell.

\section{MATERIALS AND METHODS}

\section{Preparation of chitosan films}

A $2 \%(\mathrm{w} / \mathrm{v})$ solution of chitosan was prepared by dissolving chitosan powder (TaehunBio, Kyoungbook, Korea) with a greater than 90\% degree of deacetylating in $2 \%(\mathrm{v} / \mathrm{v})$ acetic acid. The chitosan was allowed to fully dissolve over a 24hour period. The chitosan solution was evenly coated onto the surface of 24-well tissue culture polystyrene dishes (Sewon Plastic Labware, Seoul, Korea). The solution was then allowed to dry over a period of 24-hour to form a thin film. The acidity of the films was neutralized with $2 \mathrm{~mL}$ of $\mathrm{NaOH}$ solu- tion. Excess base was removed through repeat washing with distilled water until $\mathrm{pH}$ of the film returned to a physiologic range $(\mathrm{pH} 7.4)$ and then freeze-dried. Prepared chitosan coated dishes were finally sterilized by ethylene oxide before use.

\section{Covalent coupling of peptides to chi- tosan films}

Chitosan films were soaked in PBS buffer ( $\mathrm{pH} 7.4)$ for 1 hour prior to conjugation. The carboxylate groups of GRGDS (Calbiochem ${ }^{\circledR}$, Darmstadt, Germany) were activated by reaction with 1-ethyl-3(dimethylaminopropyl) carbodiimide hydrochloride (EDC) (Sigma, MO, USA) / N-hydroxysuccinimide (NHS) (Sigma, MO, USA) solution $[0.5 \mathrm{mg} / \mathrm{mL}$ of EDC with $0.7 \mathrm{mg} / \mathrm{mL}$ NHS in PBS buffer ( $\mathrm{pH} 7.4$ )] for 2 hours at $37^{\circ} \mathrm{C}$. The resulting activated carboxylate group was very reactive towards the primary amines on the chitosan, forming a stable amide bond between the peptide and the chitosan. The chitosan film were rinsed with PBS buffer, then contacted with activated GRGDS solution with various concentration in PBS buffer ( $\mathrm{pH} 7.4$ ) for 1 day at $37^{\circ} \mathrm{C}$. After the completion of peptide coupling, the films were rinsed for $5 \mathrm{~min}$. in the fresh PBS buffer solution, then rinsed twice with PBS and double distilled water to remove buffer salts, and freeze-dried.

\section{Analysis of surface characteristics using X-ray photoelectron spectrometer (XPS)}

To identify whether GRGDS were covalently bonded on the chitosan film surfaces or not, we analyzed the chemical composition of GRGDS grafted chitosan film surfaces using XPS (Surface Science Inc. Model SSX-100). After the iodination of GRGDY, iodinated GRGDY was grafted onto the chitosan surface using cross-linker as described 
above, and then XPS analysis was performed to recognize the presence of iodine on the GRGDY grafted chitosan surface. The presence of iodine indicates that GRGDY was covalently bonded on the chitosan surface. For iodination of oligopeptide, tyrosine $(\mathrm{Y})$ residue is necessary for binding iodine to oligopeptide. So, in this study, we used GRGDY, instead of GRGDS(9).

\section{Cell attachment test}

Cell attachment assays were conducted on chitosan film grafted with GRGDS on 24-well polystyrene dishes. Human osteoblast-like cells (MG-63) were maintained with complete media consisting of $\alpha$-MEM supplemented with $10 \%$ FBS, $1 \%$ antibioticantimycotic solution, $10 \mathrm{mM}$ sodium $\beta$-glycerol phosphate, $50 \mu \mathrm{g} / \mathrm{mL}$ L-ascorbic acid and $10^{-7} \mathrm{M}$ dexamethasone as monolayer cultures in $75 \mathrm{~cm}^{2}$ flasks. MG-63 cells were enzymatically lifted from the dishes using $0.25 \%$ trypsin in $4 \mathrm{mM}$ EDTA. The cells were concentrated by centrifugation at 6000rpm for $5 \mathrm{~min}$. at $4^{\circ} \mathrm{C}$ and resuspended in a known amount of media. Cell suspensions were seeded onto the surface of the wells containing GRGDS grafted and non-grafted chitosan films resulting in a seeding density of $3.5 \times 10^{4} \mathrm{cell} /$ well. The dishes were subsequently incubated in a humidified atmosphere consisting $5 \% \mathrm{CO}_{2}$ at $37^{\circ} \mathrm{C}$ for $2 \mathrm{~h}, 1$ day and 7 days.

\section{1) Cell count}

Osteoblasts were cultured for 1day and 7days on GRGDS grafted chitosan films and non-grafted films. To investigate the influence of GRGDS concentration on the cell attachment, chitosan films with various concentration of GRGDS (0.01, 0.05, 0.1, 0.25, $0.5,1.0 \mathrm{mg} / \mathrm{mL}$ ) were prepared. Medium was removed and the cells were washed twice with PBS to remove non-adherent cells. The attached cells were trypsinized with $0.25 \%$ trypsin in $4 \mathrm{mM}$ EDTA and counted with hemocytometer. Each experiment was performed at least three times. The statistical analysis were performed using SPSS (Version 10.0, SPSS Inc., Illinois, USA). One-way ANOVA test was used to assess the significance of differences in attached cell number between GRGDS grafted chitosan films and non-grafted one. The statistical power to detect the difference in attached cell number was calculated as the $95 \%$ confidence interval.

\section{2) Cell morphology analysis}

Cell morphology on the film was observed by

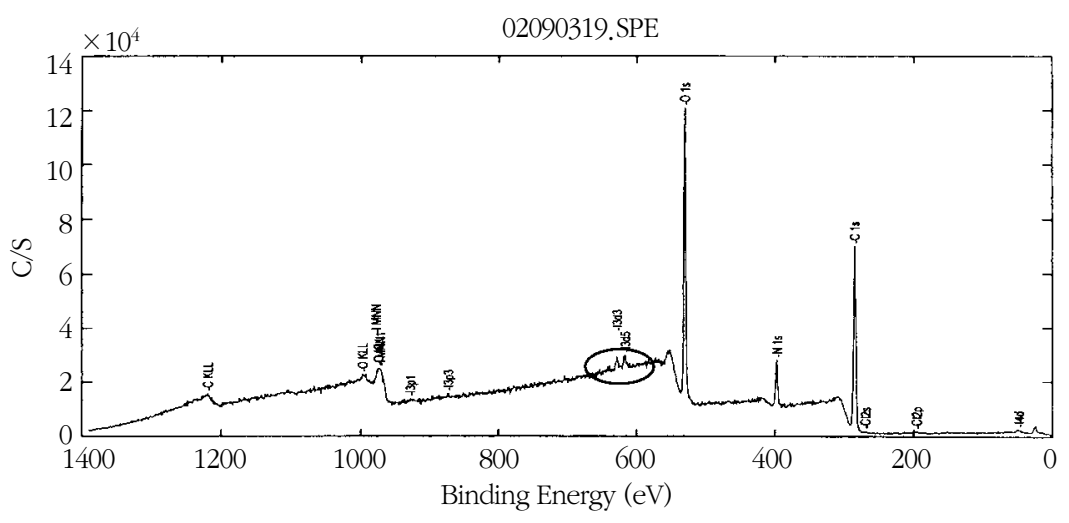

Figure 1. XPS spectrum of iodinated GRGDY grafted chitosn surface. The iodine molecules were detected on the surfaces(encircled portion). 
Table 1. Atomic concentration over the film. The iodine was detected only on the GRGDS grafted chitosan surfaces. 2 samples of each material were analyzed by XPS(scale; atom percent)

\begin{tabular}{cccccc}
\hline & C1s & N1s & O1s & Si2p & $13 \mathrm{~d} 5$ \\
\hline Chitosan & 57.10 & 6.99 & 33.99 & 1.91 & 0 \\
GRGDS-chitosan & 58.27 & 7.49 & 34.02 & 0 & 0.22 \\
\hline
\end{tabular}

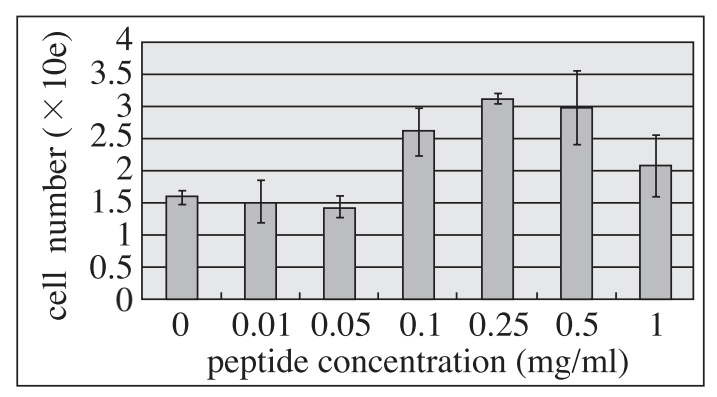

Figure 2-A. Cell attachment level on the surface of chitosan films at various soluble concentration of GRGDS for 1 day after incubation.

using SEM. MG-63 cells were fixed with 2.5\% glutaraldehyde in PBS for $30 \mathrm{~min}$. and then rinsed with PBS twice. The cells were then stained with $1 \mathrm{~mL}$ of cold $1 \%$ osmium tetraxide, placed on ice for 30 min., then rinsed with deionized water. Samples were then sequentially washed with ethanol by increasing concentration (70, 80, 90, 95, and twice $100 \%)$ for cell dehydration, then samples were allowed to air drying overnight. The fixed cell samples were examined using SEM (JEOL Model JSM 5200, JEOL Ltd., Tokyo, Japan). The cell morphology was observed at 2 hours and 1 day after culture.

\section{RESULTS}

\section{Analysis of surface characteristics using XPS}

Table 1 and Figure 1 show the result of XPS analysis. The iodine was detected on the surface of the iodinated GRGDY grafted chitosan films.

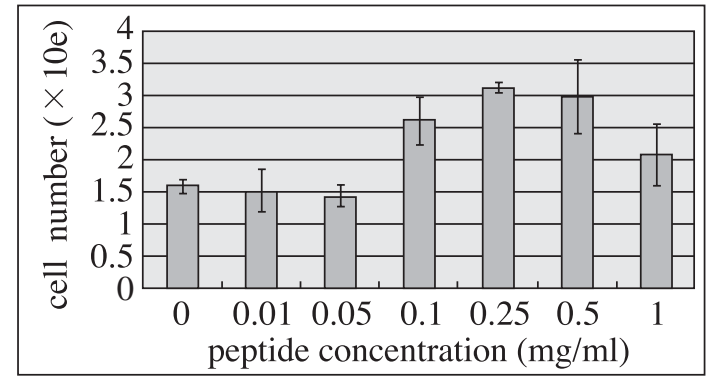

Figure 2-B. Cell attachment level on the surface of chitosan films at various soluble concentration of GRGDS for 7 day after incubation.

However, it was not detected on the surface of nongrafted chitosan films. The results indicate that chitosan film was covalently linked with oligopeptide by EDC and NHS cross-linker.

\section{Cell attachment test}

\section{1) Cell count}

The number of the attached cells on the surface of chitosan films as a function of GRGDS concentration is shown Figure 2. The level of cell attachment was determined at 1 day (Figure 2-A) and 7days (Figure 2-B) after MG-63 cells were seeded on the substrates. At 1 day, it showed that the number of attached cell was highest at soluble peptide concentrations of $0.1,0.25,0.5 \mathrm{mg} / \mathrm{mL}$. However, below $0.1 \mathrm{mg} / \mathrm{mL}$, the level of attached cell number was similar compared to non-GRGDS grafted chitosan film. Statistically significant differences $(p<0.05)$ in cell number were found between GRGDS grafted 


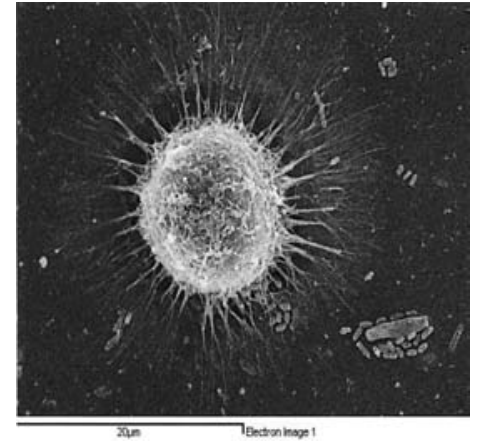

Figure 3-A. SEM image of the cell attachment onto the surface of non-grafted chitosan film for 2 hours after incubation(bar : $20 \mu \mathrm{m}$ ).

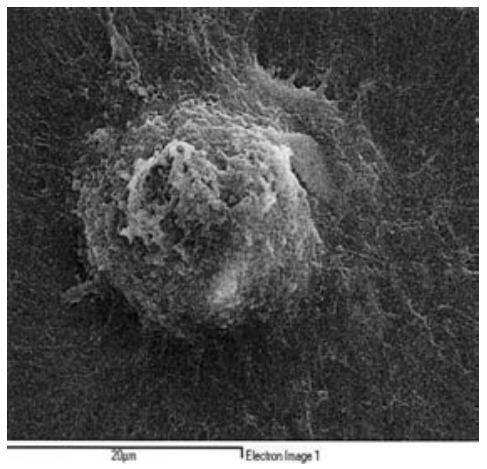

Figure 4-A. SEM image of the cell attachment onto the surface of non-grafted chitosan film for 1 day after incubation(bar : $20 \mu \mathrm{m}$ ).

chitosan at soluble concentrations of $0.1 \mathrm{mg} / \mathrm{mL}$ or greater (except $1.0 \mathrm{mg} / \mathrm{mL}$ ) and non-grafted chitosan (Figure 2-A). Accordingly, the analysis of cell morphology using SEM was performed at $0.1 \mathrm{mg} / \mathrm{mL}$ concentration. At 7 days, increased number of attached cells were observed on GRGDS grafted chitosan film, however, it was not statistically significant ( $\mathrm{p}\rangle 0.05)$ (Figure 2-B).

\section{2) Cell morphology analysis}

Figure 3-A and Figure 3-B showed the results of SEM observation of MG-63 cell attachment on the

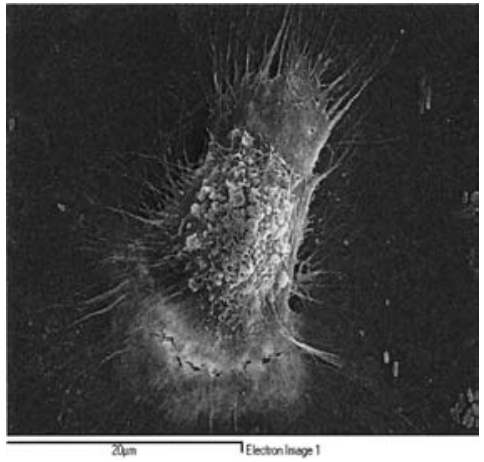

Figure 3-B. SEM image of the cell attachment onto the surface of $0.1 \mathrm{mg} / \mathrm{mL}$ GRGDS grafted chitosan film for 2 hours after incubation(bar : $20 \mu \mathrm{m}$ ).

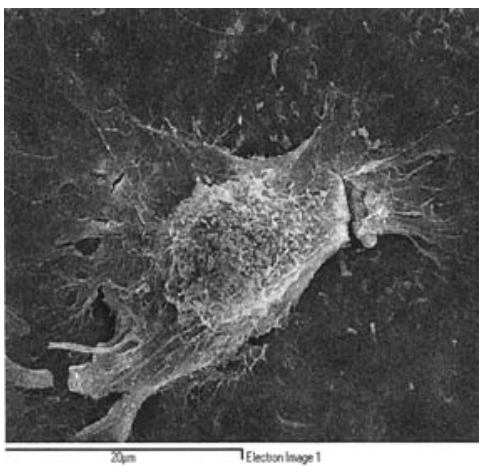

Figure 4-B. SEM image of the cell attachment onto the surface of $0.1 \mathrm{mg} / \mathrm{mL}$ GRGDS grafted chitosan film for 1 day after incubation(bar : $20 \mu \mathrm{m})$.

surface of GRGDS grafted $(0.1 \mathrm{mg} / \mathrm{mL})$ or non-grafted chitosan film after 2 hour incubation. MG-63 cultured on the substrates at 2 hours began to form a lobopodia and extend their cytoplasm.

This phenomenon was seen at GRGDS grafted $(0.1 \mathrm{mg} / \mathrm{mL})$ chitosan film. At 24 hours, MG-63 cells cultured on the GRGDS grafted chitosan film was demonstrated very well spread and more flattened stellate shapes compared to non-grafted chitosan film (Figure 4-A, 4-B). By 24 hours culture, MG-63 cells seeded on GRGDS-grafted chitosan film showed well-defined morphology, with diameters 
ranging from 10 to $20 \mu \mathrm{m}$. Cells were assumed a spindle-shaped, fusiform appearance. In contrast, osteoblasts on the surface of non-grafted chitosan film maintained a spherical to polygonal form.

\section{DISCUSSION}

The present study demonstrated that the deacetylated parts, primary amine groups of chitosan, could form amide bond with carboxyl groups of oligopeptides by using a proper cross-linker (EDC, NHS) and the GRGDS-grafted chitosan enhanced MG-63 cells adhesion than non-grafted one.

GRGDS was revealed as an effective molecule for enhancing osteoblast adhesion, proliferation and differentiation $9,10,11)$. In addition, previous studies have reported that chitosan could enhance osteoblast adhesion, proliferation and differentiation ${ }^{12,13)}$. Accordingly, we expected that GRGDS grafted chitosan was very effective material for enhancing osteoblast adhesion, proliferation and differentiation, which was further corroborated by our current study.

The results of cell number count demonstrated that covalently immobilized GRGDS onto a chitosan film promoted cell attachment of the human osteoblast like cell (MG-63). And a concentration of GRGDS which was grafted onto the chitosan surface influenced the cell adhesion. The proper soluble concentration of GRGDS was $0.1 \mathrm{mg} / \mathrm{mL}$ to $0.5 \mathrm{mg} / \mathrm{mL}$. At the concentration of GRGDS below $0.1 \mathrm{mg} / \mathrm{mL}$ or above $0.5 \mathrm{mg} / \mathrm{mL}$, cell attachment was similar compared to that onto non-grafted chitosan. Thus, an optimal concentration of GRGDS might be present, and too high or low concentration was not effective for enhancing cell attachment.

The study by Yang and Roach also showed that when GRGDS was applied for surface modification of polymers, the concentration of GRGDS influ- enced the cell adhesion and spreading ${ }^{11)}$. They demonstrated that the human osteoprogenitor cell adhesion on PLL(poly L-lysine)-GRGDS grafted PLA (polylactic acid) film was seen to follow concentration dependent attachment. In the range between $0.03 \mu \mathrm{M} / \mathrm{L}$ and $30 \mu \mathrm{M} / \mathrm{L}$, samples treated with the lowest concentration $(0.03 \mu \mathrm{M} / \mathrm{L})$ showed the maximum cell attachment.

In the present study, at 7 days the differences in attached cell number between non-grafted and GRGDS grafted chitosan was not statistically significant. This result may be interpreted that RGD played a role at the early phase of cell adhesion or possible degradation of the peptide during incubation time. And other environmental factors such as the limited surface area of culture dish and growth factors in the media fed every 3 days may influence the cell proliferation during 7 days. Therefore, in the previous studies that investigated the cell adhesion on the RGD grafted polymer, cell count was measured 1 day after incubation, ${ }^{9}$,

The difference of cell morphology was obvious between non-grafted and GRGDS-grafted chitosan. Somewhat larger regions of close contacts were formed on the GRGDS-grafted chitosan. Formation of broad close contacts in marginal regions of cells is indicative of lamellipodium formation which is characteristic activity of spreading cells ${ }^{14)}$. This suggests that the GRGDS-grafted chitosan stimulate these responses by osteoblasts more effectively than the non-grafted chitosan.

\section{CONCLUSION}

The behavior of osteoblasts on GRGDS-grafted chitosan surfaces was found to be well attached and spread compared to the behavior of cells on nongrafted chitosan. This indicates that the RGD could be suggested as an active peptide for biomimetic 
micro-environment. Due to the high biocompatibility, chitosan was used in the field of tissue engineering as a scaffold. Therefore, GRGDS grafted chitosan, biomimetic polymer surfaces, could be provided as a good material for tissue engineering. Also this material could be applied for the modification of implant material surfaces. Further related studies are needed to assess the short-term and long-term response of cells to this material in vitro as well as in vivo.

\section{REFERENCES}

1. Michalopoulos GK, DeFrances MC. Liver regeneration. Science $1997 ; 276: 60-66$

2. Langer R, Vacanti JP. Tissue engineering. Science 1993 ; 260 : 920-926

3. Shakesheff K, Cannizzaro S, Langer R. Creating biomimetic micro-environments with synthetic polymer-peptide hybrid molecules. J Biomater Sci Polym Ed 1998 ; 9 : 507-518

4. M. Dard, A. Sewing. Tools for tissue engineering of mineralized oral structures. Clin Oral Invest $2000 ; 4: 126-129$

5. Hubbell JA. Biomaterials in Tissue engineering. Biotechnology 1995; 13 : 565-576.

6. Langer R. Polymers for drug delivery and tissue engineering. Ann Biomed Eng 1995; 23 : 101111

7. Moghimi SM, Davis SS. Innovations in avoiding particle clearance from blood by Kupffer cells: Cause for reflection. Crit Rev Ther Drug Carrier Syst $1994 ; 11: 31-59$.

8. Ruoslahti E, Pierschbacher MD. Arg-Gly-Asp: A versatile cell recognition signal. Cell 1986 ; 44 : $517-518$

9. Susan S, Mary BM. Functionalized silk-based biomaterials for bone formation. J Biomed Mater Research 2001 ; 54 : 139-148.

10. Monica D, Maria TC. Novel osteoblast-adhesive peptides for dental/orthopedic biomaterials. J Biomed Mater Res $2002 ; 60$ : 466-471.

11. Yang XB, Roach HI. Human osteoprogenitor growth and differentiation on synthetic biodegradable structures after surface modification. Bone $2001 ; 29$ : 523-531.

12. Cai K, Yao K. Surface modification of poly (D,Llactic acid) with chitosan and its effects on the culture of osteoblasts in vitro. J Biomed Mater Res $2002 ; 60: 398-404$.

13. Klokkevold PR, Vandemark L. Osteogenesis enhanced by chitosan (poly-N-acetyl glucosaminoglycan) in vitro. J Periodontol 1996; 67 : 1170-1175

14. Shay JW, Walker C. Introduction to cells in culture as studied by SEM. In: Bell PB, editor. Scanning electron microscopy of cells in culture. AMF O'Hare, Chicago, Illinois: Scanning Electron Microscopy, Inc; $1984: 81$ 
-국문초록-

\section{RGD 펩타이드로 표면개질된 키토산막의 생물학적 영향}

이창균 ${ }^{1}$, 황정효 ${ }^{2}$, 이용무 ${ }^{1}$, 구영 $^{1}$, 류인철 ${ }^{1}$, 이승진 ${ }^{2}$, 한수부 ${ }^{1}$, 최상묵 ${ }^{1}$, 정종평 1

1서울대학교 치과대학 치주과학교실

2이화여자대학교 약학대학

\section{1. 목적}

생체재료의 생체친화성을 증진시키고 치유를 촉진하기 위한 목적으로 생체재료의 생화학적 표면개질에 관 한 연구가 널리 진행되고 있다. 이와 같은 목적으로 이용되어 온 부착분자에는 아미노산, 펩타이드, 단백질, 효 소 및 성장인자들을 들 수 있으며, 이들 분자들을 금속, 골대체물질 및 폴리머와 같은 생체재료의 표면개질에 이용하여 왔다. 이 연구의 목적은 생체적합성이 우수하고 생분해성을 지닌 키토산으로 얇은 막을 제작한 후, 세 포외 기질의 구성성분 중 세포부착에 관여하는 RGD 펩타이드를 부착시킨, 표면개질 키토산막의 생물학적 영 향을 MG-63 조골양세포를 이용하여 관찰하는 것이다.

\section{2. 방법}

$2 \%$ acetic acid에 키토산 가루를 녹여 만든 2\% 키토산 용액으로 24-well 배양접시의 표면을 도포 후 24시간 동안 건조시켜 키토산막을 제작하였다. GRGDS 펩타이드를 cross-linker(EDC, NHS) (Sigma, MO, USA) 용액과 반응시켜서 펩타이드의 카르복실기를 활성화시켰다. 이들을 PBS 완충용액으로 수화시킨 키토산막과 결합시켜 펩타이드의 활성화된 카르복실기와 키토산의 아민기 간에 안정적인 아미드 결합(amide bond)이 형성되도록 하였다. 하루 동안 반응을 일으킨 후 PBS 완충용액과 증류수로 씻어내고 냉동 건조시킴으로써 GRGDS가 결합 된 키토산막을 제작하였다. 재료 표면의 화학 성분을 알아보는데 사용되는 방법의 일종인 X-ray photoelectron spectroscopy(XPS) 분석을 통하여 부착분자가 키토산막에 결합된 여부를 확인하였다. GRGDS 펩타이드에 요 오드를 결합시킨 후, 이것을 키토산막에 공유 결합시키고 XPS를 통해 요오드가 재료 표면에서 검출되는지를 검사하였다. 요오드가 검출된다면 이것은 키토산막 표면에 실제로 GRGDS 펩타이드가 존재하는 것을 의미하 게 된다. 표면개질된 키토산막에 사람조골양세포인 MG-63을 접종하여 이를 실험군으로 하였고, 표면이 개질 되지 않은 키토산막을 대조군으로 하였다. 세포부착의 최적화 농도를 확인하기 위하여 GRGDS를 0.01, 0.05, $0.1,0.25,0.5,1.0 \mathrm{mg} / \mathrm{ml}$ 의 농도로 준비하였다. 배양 후 1 일, 7 일째에 각 well에서 trypsin EDTA를 이용하여 세 포를 분리한 후, 이를 원심 분리하여 세포수측정기를 이용하여 부착 세포의 수를 측정하여 세포의 부착 정도를 비교하였다. 배양 2 시간, 24 시간 후 주사전자현미경을 이용하여 키토산막에 부착된 세포의 양상을 관찰하였다.

\section{3. 결과}

$\mathrm{XPS}$ 를 통한 표면의 화학 성분 분석 결과 GRGDS 펩타이드를 결합시킨 키토산막에서 요오드가 검출되었으며 펩타이드를 부착하지 않은 대조군에서는 검출되지 않았다. 따라서 cross-linker를 이용한 펩타이드와 키토산막 의 공유결합을 확인할 수 있었다. 세포 배양 후 1 일째 부착된 세포 수를 측정한 결과 $0.1 \mathrm{mg} / \mathrm{ml}$ 이상의 GRGDS 펩타이드 농도로 공유 결합시킨 키토산막에서 부착 세포 수가 다른 농도에 비해 유의성 있게 많이 관찰되었다. 
이 농도 이하에서는 대조군과 실험군간에 세포부착의 유의한 차이가 없었다. 따라서 주사전자현미경을 이용한 부착 세포의 양상에 관한 관찰은 $0.1 \mathrm{mg} / \mathrm{ml}$ 농도의 펩타이드를 이용하였다. 세포 배양 7 일째, 부착된 세포 수 측 정 결과 GRGDS의 농도에 따른 유의성 있는 차이가 없었으며, 실험군과 대조군간에도 유의성 있는 차이가 없 었다. 주사전자현미경 관찰결과 2시간 및 24시간 배양된 실험군 모두에서 별모양의 세포들이 키토산막 표면에 편평하게 잘 부착되어 있으며 많은 위족이 발달된 소견을 보인 반면, 대조군에서는 원형 또는 다각형 모양의 세 포들이 실험군에 비해 부착이 덜 되어있는 양상을 보였다. 이 연구를 통하여 기능성 펩타이드를 생체재료의 표 면에 공유결합 시키는 방법을 확립할 수 있었으며, RGD 펩타이드의 공유결합으로 표면개질된 키토산막이 조 골세포의 부착능을 증진시킬 수 있음을 확인하였다. 표면개질된 생체재료를 소, 중동물에 적용시켜 생체 내에 서의 생물학적 영향을 평가할 필요가 있으며, 이 실험의 결과는 향후 다양한 기능성 부착분자를 선발, 고안하여 임플란트용 생체재료의 표면개질에 이용하는 이른바 모방생체재료분야에 널리 활용될 수 있을 것으로 생각된 다. 